\title{
A guerra por detrás da guerra - A batalha artística na Alemanha Nazista no período entre as grandes guerras
}

\author{
The war behind the war - The artistic battle \\ in Nazi Germany in the period between the great wars
}

\author{
Celina Borges Lemos \\ Universidade Federal de Minas Gerais, Belo Horizonte, Minas Gerais / Brasil \\ celinaborg@gmail.com \\ Danielle Amorim Rodrigues \\ Universidade Federal de Minas Gerais, Belo Horizonte, Minas Gerais / Brasil \\ danielleamorimr@gmail.com
}

Resumo: Este artigo desenvolve o estudo sobre a utilização da arte, principalmente da arquitetura, como instrumento de imposição de uma ideologia no contexto específico da Alemanha Nazista no período entre a Primeira e a Segunda Guerra Mundial, abrangendo os governos de Weimar (República de 1919 a 1933) e de Hitler (Nazismo de 1933 a 1945). Para entender melhor esse cenário foi abordado o duro conflito artístico que acontecia nos bastidores das atrocidades nazistas, entre a arte do governo e a arte revolucionária, as Vanguardas Artísticas. Com esse exemplo extremo foi possível analisar o papel social e político que a arte e arquitetura representam, o que configura o real objetivo desse texto. Logo, percebe-se que através de complexas estratégias e conceitos é possível transformar uma estrutura social como um todo, sendo que essa forma de transformar pode seguir caminhos distintos de acordo com a conjuntura presente. Isso demonstra um ciclo de relações diretas, entre a estética como instrumento e produto na dinâmica social.

Palavras-chave: arte; arquitetura; Nazismo; guerra; manipulação. 


\begin{abstract}
This article develops the study of the use of art and architecture in the imposition of an ideology: The Nazism. The period is between World War I and II, covering the governments of Weimar (Republic of 1919 to 1933) and the governments of Hitler (Nazism from 1933 to 1945). In this context, a difficult artistic conflict has been addressed which was happening behind the scenes of the Nazi atrocities. This conflict was between the art of government and revolutionary art (the 'Artistic Vanguards'). So, considering this extreme example, it was possible to analyses the real objective of this article: to understand the social and political function that art and architecture represent. In this way, it is possible to transform a social structure as a whole using art. Simultaneously, this transforming can follow different arts according to the current social situation. Those facts demonstrate a cycle of direct relations between aesthetic as an instrument and product of social dynamics.
\end{abstract}

Palavras-chave: art; architecture; Nazism; war; manipulation.

Recebido em: 30 de agosto de 2017.

Aprovado em: 6 de fevereiro de 2018.

\title{
1 Contexto
}

O século XX foi uma época de transformações e reviravoltas intensas para a humanidade em todos os seus aspectos: econômico, político, cultural e social. Entre os inúmeros momentos que compõe esse século emblemático se encontram duas grandes guerras: a Primeira e a Segunda Guerra Mundial. Sabe-se que as guerras se iniciam muito antes dos seus anos historicamente determinados de duração. Cada um desses conflitos apesentou um grande processo político, ideológico, econômico e social que precede os anos extensos de batalha. A Segunda Guerra Mundial demonstra essas questões mais claramente, uma vez que a batalha ideológica se torna um dos principais fatores dessa guerra, enquanto na Primeira a justificativa econômica traz uma sensação de uma guerra de razão capitalista e sem a noção nacionalista tão evidente nesses conflitos, vazia de ideologia (HOBSBAWN; SANTARRITA, 1995). Esse ponto do primeiro conflito também influencia enormemente a ocorrência do segundo, principalmente para os protagonistas dessa época: a Alemanha.

Para entender melhor os conflitos sociais que antecedem a Segunda Guerra Mundial no contexto da Alemanha, precursora dessa grande guerra, esse artigo irá trabalhar justamente com a disseminação 
da principal ideologia de guerra: o Nazismo, e como cada princípio dessa doutrina pôde ser a absorvido pela população, a partir de inúmeras estratégias, a ponto de se tornar verdade absoluta e um motivo de luta de uma nação inteira. Dentre as diversas estratégias de se chegar ao domínio da mentalidade da população, o Nazismo se apropriou da estética em suas diferentes vertentes e representações como principal arma, tais como: a propaganda, as artes plásticas, o cinema, a poesia, a arquitetura, o urbanismo, entre outras.

Esses caminhos artísticos para a conquista dos objetivos Nazistas surgiram desde o final da Primeira Guerra Mundial. Inicialmente, após essa grande batalha, a Alemanha estava completamente devastada em todos os âmbitos. A morte fazia parte do cotidiano dos cidadãos alemães, a dignidade e a humanidade de muitos foram perdidas após o banho de sangue da guerra e isso se manteve depois com a extensa crise econômica do país causada por sua constante instabilidade, a Crise Mundial, e os gastos com a guerra (HOBSBAWN; SANTARRITA, 1995). Assim, uma depressão geral se instalou na população, e, independente da classe social, os alemães não tinham forças para se reconstruir.

A situação foi agravada de outras duas formas, ambas de cunho político. Primeiramente, a Alemanha se encontrava em um momento de incerteza política com o surgimento de uma disputa ideológica entre grandes partidos políticos, muitos deles novos: o partido do governo estabelecido logo após a Primeira Guerra, o Governo Republicano de Weimar (1919 a 1933); o Partido Socialista, de ideais Marxistas; e o Partido da Nova Social Democracia, que depois é denominado e divido nas políticas Totalitaristas do Nazismo (a comando de Hitler, Alemanha) e Fascismo (a comando de Mussolini, Itália). A segunda razão foi a falta de engajamento político e a perda do sentimento nacionalista pelos alemães. Historicamente a Alemanha possuiu muitos governos autoritários o que não possibilitou a participação política da população e fez crescer atitudes passionais dos jovens sem um embasamento crítico (HOBSBAWN; SANTARRITA, 1995). A Primeira Guerra só fortaleceu esse cenário, uma vez que, com tantas mortes, miséria e uma nova política restritiva, mesmo que republicana, se perdeu o conceito de cidadania e a crença na unidade da nação alemã.

A identidade alemã foi perdida, juntamente com a esperança, e é nesse momento tão difícil que a arte se manifesta de forma dúbia, ou seja, o cenário político da época era tão forte que produziu duas linguagens 
artísticas principais que denominaram caminhos sociais diferentes: as artes impositivas e as artes libertadoras. A primeira linha atribuía à arte um papel direcionado para a manipulação e o domínio da população através da estética, e, assim fornecer e exaltar uma única trajetória para a reconstrução alemã: o Nazismo. Já a outra, segue a ideologia que prioriza aprimorar, artisticamente, a capacidade crítica da população perante todos os setores da sua realidade para que assim a mudança seja projetada e a identidade reconstruída pelos próprios cidadãos (HOBSBAWN; SANTARRITA, 1995).

A arquitetura, como uma grande arte do cotidiano, teve um papel importante nesse contexto. Baseado no conceito de imagens dialéticas benjaminiano, tem-se que a arquitetura enquanto projeção do desejo, não passa de uma imagem sonho e atinge uma dimensão ficcional (BENJAMIN, 1985, p.120). A arquitetura nesta conjuntura pode ser considerada uma cristalização objetiva da cultura do nazismo, da arte impositiva, e esta tinha como missão se constituir enquanto objeto de consumo imagético e utilitário. No processo de criação e produção do objeto arquitetural estão relacionados uma vontade politica e ou o poder politico de criar formas. Suas qualidades estéticas são resultado de uma linguagem legítima, hegemônica, onde interage o discurso ideológico coerente liderado pelo próprio Hitler a partir de 1933 (LANE, 1978). Esta arquitetura articulada com a construção de uma campanha propagandista materializa uma cultura representada pela força criadora denominada a vontade autoritária, ou seja, o poder político de criar formas. É neste contexto que se pode considerar a arquitetura como uma imagem artística liberada da contribuição diversa das vanguardas da época, lhe conferindo um valor simbólico e um valor de uso transformador, que redimensiona a sua recepção.

O estadista dotara a arquitetura de um papel preponderante, catalizador das artes cujas formas determinam as formas da pintura e da escultura. Portanto, considerava essa mais apta do qualquer outra enquanto reponsabilidade de expressar a unidade, a grandeza e o poder da nação. "Todo grande período encontra em seus edifícios a expressão final do seu valor." (HITLER apud LANE, 1978, P. 76). Neste sentido, defendia que a arquitetura, entre as outras artes, além do seu papel de expressar a unidade e o poder da nação poderia contribuir para criá-los. Estas reflexões são parte substantiva das ideias benjaminianas quando profetiza: "Todos os esforços para estetizar a política convergem para 
um ponto. Esse ponto é a guerra.” (BENJAMIN, 1985, p. 195). O autor mostra que, do ponto de vista politico, a guerra permite fortalecer grandes movimentos de massa, ao passo que do ponto de vista técnico o autor pondera: "[...] somente a guerra permite mobilizar em sua totalidade os meios técnicos do presente, preservando as atuais relações de produção." (BENJAMIN, 1985, p. 195).

Com a inserção da arquitetura e da arte em primeiro plano para a retomada do país como um todo, inicia-se junto à sociedade uma guerra ideológica e estética para viabilizar a comunicação direta com a população. As formas que esse diálogo poderia se estabelecer possuem ideologias que regem as representações e expressões na época, sendo uma a ideologia Nazista, que carrega uma estética dominadora, e a outra, a ideologia das Vanguardas Artísticas que em grande variedade trazem diferentes visões e soluções para a realidade presente.

\section{As Vanguardas Artísticas}

As Vanguardas Artísticas que integram o Movimento Moderno conquistam uma diversidade de interpretações e reflexões sobre esse momento vivenciado e condensa um objetivo comum de reanimar a população e seus valores com a inovação artística ao trazer um escapismo e também a construção da crítica. Nesse movimento, várias vertentes surgiram em todas as artes, cada uma com a sua linguagem de expressão, como por exemplo: na arquitetura evidenciavam movimentos como o Art Nouveau, Arts \& Crafts, e, posteriormente, o Expressionismo, o Formalismo, o Organicismo, o Neoplasticismo, o Construtivismo, entre outros; enquanto nas artes plásticas se destacavam: o Naturalismo, o Simbolismo, o Cubismo, o Impressionismo, o Expressionismo, o Surrealismo, o Dadaísmo, entre tantos outros (FER; BATCHELOR; WOOD, 1998).

Os vanguardistas reconheceram, em unidade, um papel social extremamente significativo da arte que possibilita questionar e influenciar a constante transformação da sociedade através do pensamento crítico, recurso importante principalmente na época. Para isso, uma de suas principais conquistas seria popularizar a arte, uma vez que era necessária sua presença no cotidiano de todos os cidadãos para que a influência aconteça. Dessa forma, percebe-se uma valorização do momento presente e a necessidade de criação e renovação das artes de massa 
como cinema, artes de ruas, e teatros. Nesse contexto, o contato com o passado se constituía muito mais pela valorização da memória, enquanto reminiscência, do que pela retomada dele. Em seu ensaio sobre a obra antológica do escritor francês Marcel Proust, Em busca do tempo perdido, Benjamin (1985) menciona que um acontecimento vivido é finito e pode ser considerado uma chave para o que vem depois. Já o acontecimento lembrado institui-se sem limites uma vez ser a chave para tudo que veio antes e depois. Para Benjamim (1985, p. 37), é a reminiscência que prescreve, com rigor, o modo de textura. Ou seja, a unidade do texto está apenas no actus purus da própria recordação, e não na pessoa do autor, e muito menos na ação.

Conceitualmente, o Movimento Moderno e suas vanguardas definem as três temporalidades sociais como: o passado, que é a memória e a identidade; o presente, que é a leitura do mundo ideal, e o futuro como a parte indefinida a ser conquistada (HOBSBAWN, 2013). Nesta busca de salvar o passado no presente Benjamim, segundo Gagnebin

[...] transforma o passado porque este assume uma forma nova, que poderia ter desaparecido no esquecimento; transforma o presente porque este se revela como sendo a realização possível dessa promessa anterior, que poderia ter-se perdido para sempre, que ainda pode se perder se não descobrirmos, inscrita nas linhas do atual. (GAGNEBIN, 1985, p. 16).

Essas temporalidades se fundem dentro da sociedade e projetam uma sensação de segurança para as pessoas, o que justifica esse reflexo na arte para aproximar da população. De maneira concreta isso acontecia nas artes através da inovação constante da expressão artística, como: a fusão de materiais, a ligação com o avanço tecnológico e o repúdio ao conservadorismo das academias e a reprodução constante de obras artísticas já existentes. Benjamim (1985) conceitua técnica como aquele que torna os produtos literários acessíveis a uma análise social, ou seja, análise materialista. Além disso, o conceito de técnica representa, segundo o autor, o ponto de partida dialético para uma superação do contraste infecundo entre forma e conteúdo (BENJAMIN 1985, p. 122). Este considera que a essência da obra de arte sempre foi reprodutível e que a reprodução técnica da obra de arte representava um processo novo que se desenvolveu na história intermitentemente. Outra questão fundamental na analise da politica estética da obra de arte é o seu potencial expositivo. 
À medida que as obras de arte se emancipam do seu uso ritual, aumentam as ocasiões para que elas sejam expostas. [...] a preponderância absoluta do valor de culto conferido à obra levou-a a ser concebida em primeiro lugar como instrumento mágico, e só mais tarde como obra de arte, do mesmo modo a preponderância absoluta conferida hoje a seu valor de exposição atribui-lhe funções inteiramente novas entre as quais as artísticas, a única de que temos consciência [...] (BENJAMIN 1985, p.173).

Em nome mais uma vez do diálogo com a sociedade, renova-se a importância da comunicação que deveria apresentar mensagens cada vez mais objetivas. A comunicação das Vanguardas Artísticas se dava de duas formas: entre as próprias artes, e entre o produtor e o receptor da mensagem transmitida. Referenciado na obra das Passagens de Benjamin, Rouanet afirma que a produções artísticas com a pintura, a arquitetura, na condição de imagem produzida, pode ser considerada como: “[...] uma linguagem que supõe, em todos os instantes, uma cumplicidade entre o texto montado e as imagens que ele suscita no leitor." (ROUANET, 1987, p.103).

As artes se conectavam de diversas formas, como por exemplo, a arquitetura que tangenciava muitas vezes as artes plásticas (com novas dinâmicas de perspectivas, a exploração de cheios e vazios nas fachadas e jogos de luzes nos espaços); a linguagem musical (com as noções de ritmo e leveza); e a literatura (com seu caráter metalinguístico e simbologia). ${ }^{1}$ Essas fusões também tinha o objetivo aprofundar a interlocução que estimularia o raciocínio. Para isso, a prática artística, em cada detalhe, deveria apresentar maneiras distintas de construir o significado da mensagem, o que desenvolve o racional, o irracional e a liberdade de expressão dos indivíduos.

Com todos os problemas e desafios do momento entre guerras, as vanguardas também trazem em discussão a multifuncionalidade das artes, que é uma forma das mesmas atuarem em todos os setores da sociedade. Isso acontecia a partir de uma vertente mais econômica da questão, sendo a arquitetura a arte que melhor ilustra esse processo (TAFURI; DAL CO, 1976). Dentre suas diversas utilidades, a arquitetura teve um

\footnotetext{
${ }^{1}$ Reflexões realizadas a partir da leitura dos autores: FER; BATCHELOR; WOOD, 1998; RYKWERT, 2008 e TAFURI; DAL CO, 1976.
} 
desenvolvimento que perpassava conceitos industriais e artesanais no processo de projeto e na execução das construções propostas (PAIM, 2000). Em seu campo voltado para o industrial, adotou-se a arquitetura para sanar o grande problema de Déficit Habitacional e para viabilizar, através da sua tipificação e serialização, a massificação da produção construtiva e, assim, chegar à vida das pessoas. Já a ligação com o modo de produção artesanal se dava para melhor conectar com as culturas e tradições do povo, neste contexto as ideia de John Ruskin e William Morris muito influenciaram a valorização e as práticas do Arts \& Crafts. ${ }^{2}$ Por fim, uma arquitetura voltada para a questão do naturalismo, muito presente na Europa desde a segunda metade do século XIX, refletia já um caráter antitético ao maquinismo e a desqualificação do meio ambiente, entre outros fatores. Esta simbolizava o resgate das origens da população, com a intenção de erigir paisagens referenciadas numa estética de reminiscências e de identificações (TAFURI; DAL CO, 1976).

Com tantas vertentes artísticas, diferentes estratégias representativas e um único objetivo de inovação artística e aprimoramento da crítica da população, percebe-se uma renovação na discussão estética pelo Movimento Modernista. Alguns membros das vanguardas faziam em seus trabalhos uso de cores fortes (o Expressionismo) para destacar algum fato; outros usavam um jogo de sombras em contraste de preto e branco (o Impressionismo), como uma fotografia para tornar mais realista o que estava ali representado; alguns utilizavam símbolos (o Construtivismo e o Arts \& Crafts) para uma comunicação rápida; outros representavam o fato de forma realística, para que a crueza chamasse a atenção.

Outros membros também faziam o uso da arquitetura em sua representação de ideias. Benjamin mostra que os "[...] edifícios comportam uma dupla forma de recepção, pelo uso e pela contemplação. Em outras palavras: por meios táticos e óticos" (BENJAMIN, 1985, p.165). A primeira se efetua mais pelo hábito, e menos pela atenção e contemplação. Na medida em que a arquitetura é ao mesmo tempo o protótipo da obra de arte, que permite a mais ampla recepção coletiva, esta só é possível pelo critério da dispersão. O autor introduz a ideia de recepção tátil e de recepção ótica ao analisar a reprodutibilidade técnica da arquitetura do século. Neste sentido a obra de arte para as massas

\footnotetext{
${ }^{2}$ Reflexões realizadas a partir da leitura dos autores: DYMETMAN, 2002; PAIM, 2000 e TAFURI; DAL CO, 1976.
} 
seria um objeto de diversão, mas para o conhecedor se transforma num objeto de devoção (contemplação). Nesta análise, o hábito acaba por determinar a recepção ótica, através do olhar distraído se distancia da contemplação. Portanto a produção de uma nova arquitetura na cidade gera o efeito choque, que forma no cotidiano uma sequência de imagens.

Percebe-se então que a inovação e trazer para o público a diversidade de caminhos culturais seriam a base para a retomada dos valores e identidades daquela população. Assim, com um povo forte e munido de racionalidade, a reconstrução do país não estaria muito longe de ser alcançada. Entretanto, a liberdade, o racionalismo e o senso crítico não são os caminhos desejados pelo herói alemão daquele momento.

\section{A Arte Nazista- A Arte como Propaganda}

Inicialmente no Governo de Weimar, Adolf Hitler teve seu processo de ascensão, já que a instabilidade política era o cenário da época. Logo, era necessário um herói nacionalista para direcionar o caminho da nação. Hitler explorou essa questão com fervor e a concretizou em seu governo de 1933 a 1945. Tanto em seu início na política, quanto em sua prática como Führer (Líder) da Alemanha e durante a Segunda Guerra Mundial, Hitler, assim como as Vanguardas Artísticas, percebeu a importância da arte nesse momento. Entretanto, a estética não era instrumento para abrir a mente das pessoas, mas sim para manipular e impor uma estrutura única de mentalidade, governo, economia, e cultura: O Nazismo, com a justificativa de ser a melhor forma de resgatar a Alemanha e seu espírito. Dessa forma, naquele momento, entre as duas principais guerras mundiais, outra forma de guerra acontecia em paralelo, a guerra artística (FLECK, 2014).

A força do nazismo veio da sua capacidade de diferentes tempos numa visão sintética do "Terceiro Reich" em que todos teriam acesso a felicidade. Qualquer semelhança com o Reino de Deus na terra não é mera coincidência. Boa parte da propaganda nazista e sua força de persuasão estão relacionadas a elementos sagrados ou míticos. (SOUSA, 2015, p. 46).

No entanto, o autor cita a crítica contundente de Benjamim em sua "Crônica dos desempregados alemães": “[...] o Reino de Deus os 
alcança como catástrofe, pois 'ela é algo como sua imagem inversa, o aparecimento do anticristo' [...]” (SOUSA, 2015, p. 46). Nesse cenário de valorização de concentração de poder, dentre tantos conceitos rígidos do Nazismo, sabia-se que o acesso à racionalidade, a abertura a novos estilos de representações e ao exercício intelectual seria plenamente contra, e na verdade, ameaçava a hegemonia na política. Assim, durante muitos anos, para além de tantas perseguições sociais, Hitler e seus seguidores perseguiam também representações e expressões artísticas diversas.

Primeiramente, as artes inimigas do Estado - as Vanguardas Artísticas, a arte soviética, a arte judia, entre tantas outras - eram denominadas como "Artes Degeneradas", que significa uma arte ultrapassada e em decadência. Essas artes possuíam inúmeros obstáculos para sua divulgação. As mesmas tinham que passar por extensas burocracias que cada vez mais se radicalizava em uma censura sem limites, com punições desde prisões e exílio até execuções nos campos de concentração. Outras formas de silenciar essas expressões se deram pelo desaparecimento de inúmeras obras durante o governo de Hitler. Mais de 20.000 obras foram confiscadas e enterradas em locais estratégicos, sendo que 5.000 foram queimadas e destruídas. ${ }^{3}$

Para legitimar todo esse combate, os Nazistas utilizaram de fortes estratégias para que a população se voltasse contra as "Artes Degeneradas". Foram usadas propagandas e obras de artes que escandalizavam todas as críticas possíveis a essas artes, recurso esse que teve o seu ápice em 1937 e em 1942 com três exposições importantes. Em 1937 em Munique duas exposições simultâneas, se contradiziam, de maneira bem próxima: a Entartete Kunst (Arte Degenerada), que através de percursos escuros, pichações com palavras de aversão apresentavam 650 quadros Modernistas e Judaicos; e a Exposição da Grande Arte Alemã, que em paredes limpas, iluminadas e com grandes pés direitos, exaltava os artistas germânicos e sua perfeição representativa. ${ }^{4}$ Já em 1942, foi a vez do alvo ser a arte soviética na exposição Das Sowjetparadies (O Paraíso Soviético). Através de inúmeros quadros expostos se criticava e hostilizava os modos de vida socialista (MORENO; ZAPICO, 2014).

\footnotetext{
${ }^{3}$ Reflexões realizadas a partir da leitura dos autores: FLECK, 2014 e HOBSBAWN; SANTARRITA, 1995.

${ }^{4}$ Reflexões realizadas a partir da leitura dos autores: CADERNO CULTURAL, 2013 e FLECK, 2014.
} 
Esse combate artístico intenso dos Nazistas perante as culturas e artes declaradas inimigas da sociedade alemã era de fato escancarado. Isso, como já foi tratado anteriormente, se da, principalmente, pela forma na qual a arte poderia transformar uma sociedade. Nessa visão, uma vez que Hitler e seus seguidores precisavam da mesma como uma forma de manipulação da população, a arte Nazista ganha um tom extremamente propagandístico e político, o que reforça, em todos seus princípios e estratégias, oposição as artes revolucionárias.

Em primeiro plano estão os conceitos que regem o Nazismo e a sociedade que se deseja construir - ou reconstruir - que estarão representadas em todos os âmbitos artísticos. Para a manutenção e legitimação do poder totalitário, a sociedade deveria perder suas particularidades e individualidades, e ser transformada de um coletivo para uma massa - uma unidade alienada, irracional, e automatizada perante uma ideologia. Isso caracteriza uma sociedade obediente e confiável para os Nazistas (NARVER, 1990). Sousa, ao mencionar as reflexões de Walter Benjamin e de Ernest Bloch sobre o nazismo conclui que: "[...] o nazismo arremeda o socialismo, como o anticristo imita a promessa messiânica. Bem como uma interpretação teológica e política sobre o nazismo, escapando de análises meramente econômicas." (SOUSA, 2015, p. 58).

Assim, com esse propósito maior, os conceitos essenciais nazistas deveriam se adentrar na sociedade. Os princípios essenciais eram o nacionalismo, o ódio, o racismo, o territorialismo, a ciência, e o conceito de Nietzsche sobre política, todos eles interligados entre si e de certa maneira se justificando. É importante perceber que essas teorias e valores não são inéditos, porém era a forma como o Nazismo se apropriava deles que provocava uma releitura deturpada de conceitos, que direcionava os princípios sociais para um novo caminho.

O Nacionalismo era tratado de uma forma extremamente agressiva com o objetivo de encontrar uma origem comum, estrategicamente selecionada, que unificasse os alemães (POLLIG; SUHLE; HAIST, 1985). Isso acontecia pela necessidade de segregar e apagar as pessoas que não faziam parte dessa nação, os chamados inimigos do Estado (judeus, socialistas, ciganos, negros e deficientes), e assim, diminuir questionamentos e ameaças ao poder nazista. Esse conceito se relaciona com mais dois princípios importantes: o territorialismo e o racismo. 
O territorialismo traz a espacialização do conceito de identidade de um povo. Dessa forma, o espaço contém o povo e o povo se apropria do espaço, e o restante da população que não se encaixa na nação se torna excluída de sua identidade e do espaço, gerando a expulsão dos inimigos da nação da Alemanha. Essa noção do poder do espaço também pode ser percebida em uma escala menor. Na Era Hitlerista a maior forma de exclusão e de retirar a cidadania de uma pessoa era a expulsão da mesma do seu lar, pois, uma vez sem casa o cidadão perdia sua identidade e concretiza-se o seu não pertencimento a aquele bairro, cidade e nação (ZEVI, 2002). Hebert Marcuse, citado por Sousa, esclarece esta análise:

[...] mostra como a unidade nazista se realizou pela criação de um clima patético e irracional, a partir do conceito de "povo" (volk), associado ao sangue (Blut) e ao "solo" (Boden). Se naturalizara desta forma o social, enraizando-o de um lado no sangue, isto é, a raça no seu sentido mais biológico e irracional, de um outro lado no solo, ou seja, a terra no seu sentido mais sentimental. (SOUSA, 2015, p. 47).

O racismo está por trás de todas essas políticas, está na segregação social estabelecida nessa identidade seletiva da nação alemã, e justificada pela ciência, novamente em releitura própria. Segundo a Teoria de Darwin da Seleção Natural das Espécies existe uma luta, natural para a sobrevivência das espécies no meio ambiente. Porém, essa teoria foi interpretada como a justificativa para a luta entre as chamadas raças superiores (os alemães puros) e as raças inferiores (os inimigos do Estado), para os nazistas (DYMETMAN, 2002). As descrições científicas dos fenótipos dos animais e plantas se tornaram uma forma de classificar padrões físicos para cada raça, e assim, classificar, excluir, punir e até eliminar as raças indesejáveis.

Para legitimar toda essa barbárie, Hitler faz uso de mais uma teoria: a política segundo Friedrich Nietzche e os conceitos de lei e poder. A partir de uma leitura própria sobre o assunto, o líder Nazista transformou a ideia de que a arte estava sempre conectada com questões econômicas e sociais em uma ideia de que o uso da arte deve ser em prol de imposições políticas (GAY, 1978). Mais que isso, Hitler reinterpretou o que é lei e poder, pois o mesmo estabeleceu que lei é uma proteção racional, e, assim, qualquer atitude irracional, fora da lei, era legitimada 
uma vez que poder significa (de forma bem semelhante a ideia anterior) usar a força de maneira ética (DYMETMAN, 2002). Assim, com a possibilidade de solução através da morte, o ódio se instaurou. Era necessário excluir para se unir, determinar o diferente para se identificar e responsabilizar a dor para que a nação volte a se reerguer, e a arte foi um dos instrumentos escolhidos para estimular tais ações.

A arte Nazista se inseriu na base do discurso de Hitler como propaganda e simbologia do grande monumento e espetáculo que era a própria política Nazista. A arte se dava como uma forma de manipular e gerar o consumo de ideias de forma imperceptível e sutil, sem que o receptor perceba o que está absorvendo (NARVER, 1990). Então, assim como se fazia com as grandes teorias que regiam os conceitos Nazistas, as representações artísticas apresentavam novas versões de uma mesma verdade em alta escala de produção para que conceitos fossem banalizados e atingissem toda a população.

Esses, mais do que princípios propagandísticos, eram princípios políticos, uma vez que a busca de confiança e legitimidade para a manutenção do poder, faz da política a arte da manipulação em sua essência. Isso faz com que, em um contexto de uma nação destruída, o surgimento de um herói, Hitler, e o renascimento de uma sociedade através do ódio fossem possíveis pela propaganda e seus novos recursos artísticos. Um deles era evidenciar a parcialidade e a agressividade com o objetivo de construir uma cultura hegemônica, a alemã, e passar todos aqueles conceitos para a população (JOHNSON, s/d). Essas expressões despertavam na sociedade um contato passivo e sentimental perante as questões representadas e uma absorção de ideias de forma irracional. Assim, eram usadas imagens de medo e ódio quando retratado os inimigos do Estado e de amor, força e heroísmo para os conceitos e os símbolos Nazistas.

Tamanha violência artística era justificada por uma ideologia que regia o trabalho com a propaganda e a arte de massa: a "Ideologia de Guerra" (NARVER, 1990). Esse pensamento é um conjunto de métodos políticos baseado nas estratégias reais de guerra. Dessa forma, a propaganda trazia: a homogeneização e a generalização dos alemães contra outros grupos; a intimidação da população perante os inimigos do Estado; e a idealização de um futuro próspero que o Nazismo iria trazer para aquela sociedade, tal como a guerra que massifica os soldados, idealiza a vitória e produz o medo como motivação. "Quando o inimigo adquire um 
rosto e possui uma história, torna-se impossível mata-lo" (DYMETMAN, 2002, p. 89). Com essa abordagem a propaganda se torna a própria censura perante a sociedade. Mais que isso, os artistas do governo também eram completamente vinculados a esse sistema, pois eram voluntários, e, portanto, são mais confiáveis aos olhos do governo e seguiam a risca todas aquelas burocracias e controles já citados nesse texto.

A simbologia era outro recurso importante. Signos óbvios e de rápido entendimento eram estampados nas ruas, monumentos e casas para que o contato fosse constante a ponto de fazer parte do cotidiano dos cidadãos e ser associado à melhoria da realidade deles. É nesse cenário em que a arquitetura e o urbanismo entram também como um forte instrumento de uma arte propagandística, uma vez que são espaços que abrigam o cotidiano e a dinâmica de uma sociedade ampliando o contato dessas pessoas com a ideologia de forma sutil. "A arquitetura apresenta uma importância não pela sua imagem, mas por conta de seu uso" (ZEVI, 2002, p. 21).

A arquitetura também seguia métodos de manipulação da população. Primeiramente, a arquitetura era um importante recurso de massificação da sociedade, uma vez que possui diferentes escalas de materialidade (desde pequenas residências até grandiosas edificações), e assim, consegue atingir diversas escalas sociais e a sociedade como um todo. As escalas e os ornamentos arquitetônicos também eram importantes para diferenciar os diferentes grupos sociais e seu grau de importância no país, ou seja, a arquitetura também era um objeto para a segregação social e para espelhar a hierarquia social imposta pelos Nazistas. Um exemplo disso é a diferença na dimensão das casas, os ornamentos e a localização entre classes mais favorecidas e as menos. Além disso, muitos dos excluídos socialmente tinham suas residências localizadas onde o transporte público não passava o que dificultava o acesso ao centro da cidade e às instituições de poder político. ${ }^{5}$

A hierarquia estampada na arquitetura e no urbanismo também era de representatividade política. Todos os edifícios de cunho político eram monumentais e se impunham na paisagem o que demonstrava que a política estava a cima de todos os cidadãos comuns. Além disso, os edifícios institucionais possuíam uma hierarquia em seu ambiente

\footnotetext{
${ }^{5}$ Reflexões realizadas a partir da leitura dos autores: HOBSBAWN; SANTARRITA, 1995; NARVER, 1990.
} 
interno que deveria demonstrar a sobreposição da nação alemã perante os outros países que a visitavam politicamente de tempos em tempos. Esses visitantes possuíam acessos e acomodações distintas dos líderes nazistas, muitas vezes eram espaços estreitos, em níveis inferiores, com pés direitos pequenos que davam acessos a um espaço extremamente rico, soberbo e amplo onde Hitler os recebia. Além disso, outra demonstração dessa hierarquia internacional eram as estratégias de internacionalização da Alemanha pela arquitetura. Hitler investiu intensamente no turismo com a criação de grandes resorts e passeios turísticos que destacavam os aspectos positivos do estilo de vida alemão nazista (WOODS, s/d).

Ao retomar a ideia de irracionalizar a população, a arquitetura, inspirada na política do Panem et Circenses (Pão e Circo) da Roma Antiga, também se destacava pelas grandes obras de entretenimentos como locais de exposição, estádios e teatros. Essas foram realizadas para alienar os cidadãos perante a situação ruim que o país passava e as atrocidades e imposições do regime (NARVER, 1990).

$O$ resgate da identidade, objetivo que a arquitetura também procura alcançar na sociedade, era dado através de duas principais estratégias (em escalas distintas): pelas habitações e pelas grandes obras. As residências possuíam características construtivas e estéticas de caráter rural (retorno das coberturas tradicionais com inclinações significativas e estrutura em madeira em evidência, proporção entre as aberturas, entre outras características). Dessa maneira, a cidade sofreu um processo de ruralização das tipologias residenciais existentes já que era uma maneira de retomar o histórico rural do país (WOODS, s/d). Além disso, as residências teriam um aspecto de familiaridade e aconchego, o que exaltaria o processo de melhorias sociais. O interno dessas casas seria o oposto de suas fachadas, com um materialismo e a modernidade da indústria estampada nos móveis e adornos, o que também demonstra a melhoria financeira e de poder da população. Percebe-se então, mais um princípio da propaganda que é transmitir a mesma mensagem em diferentes versões de representação.

Assim, com o retorno da valorização de uma estética rústica e mais antiga na cidade, as grandes obras também buscaram esse retorno histórico a partir da Theory of Ruin Value (Teoria das Ruínas) de Albert Speer, o arquiteto e braço direito oficial de Hitler (NARVER, 1990). Essa teoria tratava da readaptação do passado no presente através da restauração de monumentos históricos das cidades alemãs e de construção de novos 
objetos com conceitos históricos representados em novas estruturas. Essa teoria foi a maneira encontrada pelos nazistas de inserir a tradição no cotidiano e uni-los aos aspectos de modernidade no desenvolvimento econômico que estava crescendo durante o governo de Hitler.

Outra teoria importante de representação arquitetônica era a teoria do "Muro Opaco", ou seja, a arquitetura deveria ser neutra, com poucos ornamentos (para que se tornasse apenas um plano de fundo para a inserção das propagandas e signos Nazistas), e grandiosa (para esconder os problemas do regime), assim como um muro (CURTIS, 2008).

Como tantos objetivos e estratégias a arquitetura Nazista ganha processos padrões de projetos e execuções que são compatíveis com esses conceitos. Projetualmente, a arquitetura e o urbanismo deveriam ser: didáticos, para facilitar a comunicação; teatrais, para explorar o irracional do usuário; representativos, para transmitir a simbologia; e ditatoriais, para demonstrar o domínio e a subordinação do cidadão para/com o governo (NARVER, 1990). Entre os estilos que guiam esses projetos, todos possuem um fator histórico de influência importante, os principais são: a arquitetura da Grécia e Roma Antiga, que inspiram pela estrutura da "Cidade do Espetáculo", a estrutura da polis (a "Cidade Política"); o estilo Gótico, que através das catedrais representavam a subordinação da fé a um ser superior, o que assemelha a subordinação imposta pelo Führer (Líder); o urbanismo da Idade Média, que trazia o processo de ruralização das cidades; a arquitetura do Egito Antigo, que inspira em sua monumentalidade política; e os Planos da Era Napoleônica de expansão do território e de construção, compatíveis com o Plano de Construção de Hitler e sua ideia de Expansionismo (NARVER, 1990).

Nesse contexto, várias obras foram propostas e algumas delas construídas. Principalmente, o que diferencia o desenvolvimento da arquitetura nazi do resto da história arquitetônica europeia, fora o grau de significação ideológica atribuída pelos líderes nazistas, foi também a intensidade da propaganda política que a rodeava (LANE, 1978). Vale destacar que a "Ideologia de Guerra" se manteve também na arquitetura, pois os conceitos principais de manipulação regiam também as cidades, nesse momento, nazistas. A estética então foi utilizada como um catalisador da violência, exclusão, ódio, e até da própria guerra, através de uma guerra silenciosa e um domínio ardiloso instrumentado pela arte cotidiana. Alguns exemplos concretos desses valores são a Arquitetura de Guerra e a Reconstrução de Nuremberg. 
A Arquitetura de Guerra tem como o objetivo prático o avanço dela mesma, no caso, da Segunda Guerra Mundial. Dentre os diferentes elementos dessa arquitetura estão os grandes muros, a arquitetura aeronáutica e a cultura bélica. Os muros eram essenciais nas construções nazistas para ilustrar a opressão e os limites para a população, e complementavam a monumentalidade do edifício (MORENO; ZAPICO, 2014). A arquitetura aeronáutica era um importante objeto representativo do poder construtivo, internacional e de guerra. Além disso, os aeroportos, as escolas, e os ministérios desse setor eram referências de tecnologia construtiva, pois apresentavam estruturas independentes dos sistemas da cidade e sua monumentalidade não estava no destaque na paisagem, e sim, na concordância com ela (ALVAREZ, s/d). A cultura bélica se manifestada pela arquitetura e as outras artes através de recursos visuais que intimidam e, assim, legitimam o armamento da nação (MORENO; ZAPICO, 2014).

Já em Nuremberg, a sua reconstrução passou por dois princípios importantes: o Volksgemeinschaft (Comunidade do Povo) e o Cathedral of Light (Catedral da Luz) (WOODS, s/d). O primeiro conceito visa trazer uma reforma urbana voltada para a população, na melhoria da sua qualidade de vida e também na manipulação da mesma. O segundo conceito complementa o anterior, pois traz a intenção de "iluminar" o futuro da população. Assim, as principais obras foram: The German Stadium (O Estádio Alemão), o maior estádio do mundo na época, que reforça a ideia da arquitetura de entretenimento e a inspiração nas grandes arenas gregas (NARVER, 1990), e grandes e largas avenidas de ligação entre prédios institucionais e sedes do partido Nazistas, que proporcionavam espaços para marchas e celebrações em prol do governo, algumas denominadas até como March Field (Campo de Marcha) (NARVER, 1990).

\section{Conclusões}

A estética não só acontecia em paralelo a grande guerra de fato, como também a representava literalmente. Essa violência artística estudada, assim como a politização da arte, torna possível a percepção do real potencial de transformação social através dos recursos e das tipologias artísticas. Isso acontece, pois a arte possui inúmeras formas de representação e interpretação que proporcionam o alcance de todos 
os âmbitos que compõe uma sociedade. Além disso, a arte também possibilita a transmissão de mensagens de maneira sutil e impactante, trazendo então a sua tendência propagandística e assim, seu efeito propaganda também: de indução e manipulação do receptor para o consumo de uma ideia.

Dessa mesma forma, se encaixa, até de maneira mais eficaz, a arquitetura e urbanismo, uma vez que faz com que essas estratégias e os princípios estudados estejam no cotidiano dos cidadãos e em sua realidade. Portanto, percebe-se, durante todo esse artigo, o quanto a concepção do espaço influencia na mentalidade das pessoas, fazendo com que a linha tênue que divide a liberdade da imposição seja algo extremamente importante no momento da concepção arquitetônica. Isso se justifica pela constatação do impacto direto da arquitetura e do urbanismo na transformação da dinâmica social, e vice-versa.

\section{Referências}

ÁlVAREZ, T.M. La Arquitectura del III Reich. Revista de Artes y Humanidades, n. 6, p. 160-171, [s./d.].

FER, B.; BATCHELOR, D.; WOOD, P. Realismo, racionalismo, surrealismo: a arte no entre-guerras. São Paulo: Cosac \& Naify, 1998.

BENJAMIN, W. A obra de arte na era da sua reprodutibilidade técnica. In: Paulo, 1985 .

. Obras Escolhidas l. Magia e técnica. Arte e política. São

BENJAMIN, W. Obras Escolhidas l. Magia e técnica. Arte e política. São Paulo, 1985.

CADERNO CULTURAL. A “Exposição de Arte Degenerada” de 1937 em Munique. 2013. Disponível em: <http://www.pco.org.br/cadernocultural/a-exposicao-de-arte-degenerada-de-1937-em-munique/azoe,a. html>. Acesso em: ago. 2015.

CURTIS, W. J. R. Arquitetura moderna: desde 1900. 3. ed. Porto Alegre: Bookman, 2008.

TAFURI, M.; DAL CO, F. Modern Architecture/1: History of World Architecture. Milão: Editora Electa, 1976. 
DYMETMAN, A. Uma arquitetura da indiferença: A República de Weimar. 1. ed. São Paulo: Perspectiva, 2002.

FLECK, I. Galeria em Nova York recria mostras do Regime Nazista. Nova York, 2014. Disponível em: <http://www1.folha.uol.com.br/ ilustrada/2014/03/1430287-galeria-em-nova-york-recria-mostras-doregime-nazista.shtml>. Acesso em: ago. 2015.

GAGNEBIN, J.M. Prefácio - Benjamin ou a história aberta. In:

Obras Escolhidas l. Magia e técnica. Arte e política. São Paulo, 1985. p. 7-19.

GAY, Peter. A cultura de Weimar. Rio de Janeiro: Paz e Terra, 1978.

HOBSBAWM, E. J.; SANTARRITA, M. Era dos extremos: o breve século XX 1914-1991. 2. ed. São Paulo: Companhia das Letras, 1995.

HOBSBAWN, E. J. Tempos fraturados: cultura e sociedade no século XX. 1.ed. São Paulo: Companhia das Letras, 2013.

JOHNSON, L. W. Propaganda and Ideology: The Architecture of Tird Reich. [s./d.].

LANE, B. M. La Arquitectura nazi. In: SUST, X. (Ed.). La Arquitectura como símbolo de poder. Barcelona: Tusquets Editor, 1978. p. 71-114.

MORENO, A. C. C; ZAPICO, M.A. L. La Gran Exposición Anticomunista del Tercer Reich: Das Sowjetparadies (1942). Diacronie: Studi di Storia Contemporanea, v. 2, n. 18, p. 1-24, 2014.

NARVER, J. D. The Cultural Production of Domination in Nazi Germany: Architecture as Propaganda. 1990. 121 f. Tese (Concurso de Mestrado em Artes no Departamento de Comunicação) - University of Toronto, Toronto, 1990.

PAIM, G. A beleza sob suspeita: o ornamento em Ruskin, Lloyd Wright, Le Corbusier e outros. Rio de Janeiro: Jorge Zahar Editor, 2000.

POLLIG, H.; SUHLE, V.; HAIST, E. (Org.). Gráfica crítica na época de Weimar. Stuttgart: Institut für Auslandsbeziehun, 1985.

ROUANET, S. P. As razões do Iluminismo. São Paulo: Companhia das Letras, 1987.

RYKWERT, J. The Judicious Eye. Chicago: Editora Chicago, 2008. 
SOUSA, R. B. Estetização da política e politização da arte: a estética do fascismo nas obras de Walter Benjamin. Revista Espaço Acadêmico, n. 171, Ano XIV, 2015. Disponível em:<http://www.periodicos.uem.br/ ojs/index.php/EspacoAcademico/article/viewFile/26904/14967>. Acesso em: ago. 2017.

WOODS, C. Assessing the Role of Architecture as Propaganda in the Tird Reich. MHIS321 Twentieth Century Europe, p. 107-115, [s./d.].

ZEVI, B. Arquitetura e Judaísmo: Mendelsohn. São Paulo: Editora Perspectiva, 2002. 